\section{Healthy eating as a trend: consumers' perceptions towards products with nutrition and health claims}

\author{
Paulo Duarte ${ }^{1}$ \\ Mariana Teixeira ${ }^{2}$ (D)
}

Susana Costa e Silva ${ }^{3}$

\begin{abstract}
Purpose - The number of food products containing nutritional or health claims, such as added calcium for stronger bones, has been increasing. Accordingly, we aimed to understand consumers' perceptions towards products that are considered to be healthier and to know how these perceptions affect their purchase intentions.

Theoretical framework - Based on consumer perception theory and how consumers process and interpret information, we sought to better understand consumer behavior in relation to the use of nutrition claims in marketing communication.
\end{abstract}

Design/methodology/approach - A survey was conducted via an online questionnaire and responses were obtained from 477 Portuguese consumers.

Findings - The results show that the most relevant characteristics when purchasing food are price and taste. However, the addition of a claim can increase purchase intentions.

Practical \& social implications of research - The reasons behind the new offerings by the food industry are related to the growing demand from individuals for products aimed at improving their health status, which has been deteriorating due to factors such as sedentary lifestyles, longer life expectancy, and a poor diet in terms of nutrition. It is important to know if these claims translate into effective changes in purchasing behavior.

Originality/value - The results lead to the conclusion that claims are important in the food choices of the Portuguese respondents, who are less keen on "light"

1. Universidade da Beira Interior, Research Unit in Busienss Sciences (NECE), Covilhã, Portugal

2. Universidade Católica Portuguesa, Católica Porto Business School, Porto, Portugal

3. Universidade Católica Portuguesa, Católica Porto Business School, Porto, Portugal

\section{How to cite:}

Duarte, p., Teixeira, M., Silva, S. (2021). Healthy eating as a trend: consumers' perceptions towards products with nutrition and health claims. Revista Brasileira de Gestão de Negócios, 23(3), p.405-421.
Received on:

06/16/2020

Approved on:

03/12/2021

Responsible Editor:

Prof. Dr. Francisco José Liébana

\section{Evaluation process:}

Double Blind Review

\section{Reviewers:}

Wilian Ramalho Feitosa; One of the reviewers decided not to disclose his/ her identity

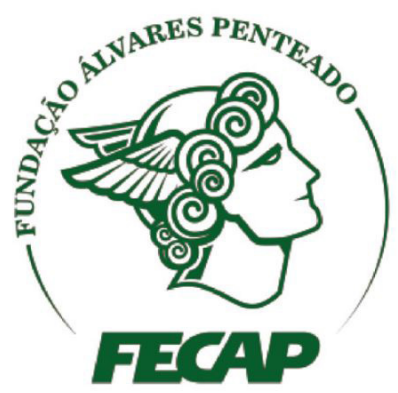

Revista Brasileira de Gestáo de Negócios

https://doi.org/10.7819/rbgn.v23i3.4113 
and "lean." When it comes to using claims in communication, in Portugal, it is always better to use a direct, transparent, and rigorous approach; otherwise the consumer will not be induced to buy.

Keywords - consumer behavior, nutrition claims, health claims, food, health perception.

\section{Introduction}

The so-called developed world is currently facing health problems due to the lifestyle adopted by most consumers (Aschemann-Witzel, Maroscheck, \& Hamm, 2013), which is characterized by more sedentary behavior and a nutritionally poorer diet (Shields \& Tremblay, 2008). Excess weight, in particular, is becoming a true public health crisis that threatens to alter the quality of life for millions of people. The number of overweight and obese individuals has skyrocketed in recent decades (Hanson \& Yun, 2018). In fact, global obesity nearly tripled between 1975 and 2016, with more than 1.9 billion adults, nearly 41 million children under the age of five, and more than 340 million adolescents being overweight or even obese (World Health Organization, 2018).

Obesity in conjunction with an aging population, which also has a higher incidence in developed countries (World Health Organization, 2007), has caused an increase in health care costs, so the promotion of quality of life as a result of better health is considered to be crucial (Kaur $\&$ Das, 2011). Thus, it is not surprising that there has been a growth of government policies focused on the promotion of healthier habits and preventive measures against diseases resulting from the absence of such habits.

Given this context, the importance of more nutritionally-adjusted food choices and different eating habits has been highlighted, both in the media and in academic research, namely related to food choice factors (Saba et al., 2010). Health has been identified as the most relevant trend driving innovation in the global food and beverage market (Meziane, 2007), which, coupled with advances in technology, provides companies with opportunities to develop an almost infinite range of new nutritionally-adjusted food concepts, such as sweeteners and light, fortified and functional products (Saba et al., 2010). This increased visibility and consumer awareness of healthy eating, combined with the prevalence of obesity, has led the food industry to reformulate products and market them as healthier alternatives (Menrad, 2003). This strategy has proven beneficial, as food companies are financially rewarded for introducing new products with higher sales growth when compared to the introduction of new products that are considered to be less healthy (Hanson \& Yun, 2018).

However, despite consumers expressing positive evaluations about these healthier options, their purchase intentions do not always match what they claim. There are differences in perceptions between added ingredients (e.g., fiber) and reduced ingredients (e.g., sugar), with the former being more highly valued than the latter (Hanson $\&$ Yun, 2018). The negative inferences they make regarding the attributes of these foods can explain this apparent difference between consumers' positive attitudes towards these products and their purchase intentions, such as the taste being less pleasurable compared to traditional versions, the price being higher, and the availability being lower (Loebnitz \& Grunert, 2018). It should also be noted that, as it is a relatively recent trend, there is still some skepticism on the part of consumers regarding the type of claims that are made, particularly regarding their veracity (Tyre, 2002).

The motivation to study this topic arises from the fact that healthy eating has become a growing trend (Aschemann-witzel, Maroscheck, \& Hamm, 2013), especially in developed countries such as Portugal (Nunes \& Pereira, 2016). This trend is visible in the opening of new commercial establishments that only sell these types of products, in the increase in the area made available for these types of products in supermarkets and hypermarkets (Ramalho, 2017), and in the growth of online stores, which all show that there is greater food awareness among consumers (Hung, Grunert, Hoefkens, Hieke, \& Verbeke, 2017). Food products that are marketed in this way stand out from the rest because they contain nutritional and health claims.

According to Kantar World Panel (2018), the Portuguese have shown a greater demand for healthier alternatives, with sales volume increasing by about $2.4 \%$ in 2016, in contrast to the food and beverage sector, which generally shows a decreasing trend (Kantar World Panel, 2018). The aforementioned source indicates that $6.1 \%$ of food purchases made by the Portuguese are of foods and beverages that are considered to be healthier (Kantar World Panel, 2018), these being ones that contain ingredients 
such as soy, oats, carob, granola, or that are lactose-free, gluten-free, have reduced sugar or salt content, or are labeled light or low-fat, as well as wholefoods and organic and functional products. According to the same source, in the United Kingdom, the same type of products saw a $36 \%$ increase in sales and are already present in about half of homes.

Considering the growing relevance of this product category, in order to answer the research question "How do consumers perceive products with health and nutrition claims?" the overall objective of this paper is to understand how consumers' perceptions are affected by nutrition and health claims on foods, by studying the impact these claims have on purchase decisions.

This article begins by presenting the categories of healthy foods, the types of claims made on food products and consumer behavior, and healthier alternatives. It then presents the chosen methodology. This is followed by the presentation and analysis of the results and their interpretation, comparison, and discussion. Finally, the conclusions are presented, which summarize the findings to meet the objectives and answer the research question.

\section{Literature Review}

\section{I Healthy Food Categories}

Nowadays, there are several words used by food brands to distinguish healthier versions from traditional versions. While the goal is always to allude to a possible health benefit, either by adding or reducing a nutrient, the words used help clarify what distinguishes the new alternative from the standard version.

\section{I.I Diet/zero/light/whole foods}

A food is considered to be "light" when there is a reduction of at least $25 \%$ of a nutrient, relative to the reference product - the traditional version. Additionally, food products can be labeled as "diet" or "zero." Both cases involve food products in which one or more nutrients, such as salt or sugar, are totally removed. However, and more predominantly in these versions, there may be an increase of other less beneficial nutrients, such as fat, so that the food does not lose flavor compared to the classic version (Gravel, Doucet, Herman, Pomerleau, \& Bourlaud, 2012). There is also the denomination of "lean" and "whole." The first denomination refers to food products that do not have a fat or sugar content higher than 5 grams per 100 milliliters/grams. The second refers to foods that make full use of the grain, i.e., foods that, despite being industrialized, maintain all their characteristics and nutrients (Gravel, Doucet, Herman, Pomerleau, \& Bourlaud, 2012).

\subsection{Functional foods}

During the last two decades, knowledge of the influence of diet on health and well-being has increased considerably, which has led to the design of new and healthier foods, reducing the risk of various chronic diseases. Foods designed in this way are called functional foods and are traditional foods modified in ways that have health benefits compared to unmodified products. The term was first used in Japan (Kaur \& Das, 2011).

A widely accepted definition states that food is functional if "it has been satisfactorily demonstrated to beneficially affect one or more functions in the body, beyond the appropriate nutritional effects, in a way that is relevant to improved health status and well-being and/ or a reduction in disease risk" (Aschemann-Witzel et al., 2013, p. 68). Several elements have converged and driven the development of functional foods, most notably the evident demographic changes, the aging population, food safety, the loss of the traditional food culture, awareness of deteriorating personal health caused by hectic lifestyles, poor convenience food choices, and a competitive food market (German, Schiffrin, Reniero, Mollet, \& Pfeifer, 1999). Other factors that have also influenced its emergence have been insufficient exercise, increased self-medication, greater information from health authorities, nutritional information, the link between diet and health, and scientific developments in nutrition research (German et al., 1999).

\subsubsection{Organic food}

Organic food results from a farm management and food production system that promotes environmental protection and animal welfare and avoids pesticide contamination (Lee \& Yun, 2016). The demand for local, sustainable, organic food production has been increasing (Stagl, 2002). Organic farming tends to improve biodiversity and sustainability in rural communities and has become one of the fastest-growing agriculture segments in many parts of the world. On average, $5 \%$ of the European Union territory is being used for organic production, with Italy's organic market being the largest, followed by Germany and the United Kingdom (Helga \& Yussefi, 2007). 
The organic food market has been developing rapidly, with annual growth rates of $10 \%$ over the last two decades. In Europe, the organic market is worth about 20 billion euros annually and already represents an estimated $1.5 \%$ share of the total food market. However, throughout Europe, there is a very high importation rate (especially for fruits and vegetables) as the production rate is much lower than the demand for organic products. This growing demand for organic products offers considerable opportunities for producers in developing countries (European Court of Auditors, 2012).

\subsection{Types of claims on food products}

\subsection{Health and nutrition claims}

In the context of Regulation (EC) No. 1924/2006 (European Commission, 2007), health claims state, suggest, or imply a relationship between a food or food category and health. Examples include claims referring to the growth and development of children or claims of reducing the risk of disease. Health claims are based on generally accepted scientific knowledge and are referred to as "Article 13.1 claims". One example is: "this product contains calcium; calcium is relevant for the development of strong bones and teeth."

On the other hand, nutritional claims state, suggest, or imply that a food has particular beneficial nutritional properties due to the energy it provides or the nutrients it contains. Examples include: "this product contains calcium" and "this product is low in sugar." Explicit conditions are described in EU Regulation 1924/2006 for claims such as "source of," "rich in," "reduced fat," "reduced energy," and "fat-free" (Verhagen, Vos, Francl, Heinonen, \& Loveren, 2012).

Derby and Levy (2005) concluded that consumers place greater importance on health claims than nutrition claims. However, this is not a global trend. For example, according to an online questionnaire involving participants from the UK, US, Germany, and Italy (Trijp \& Lans, 2007), it was found that the different types of claim do not affect the perception of food being more or less healthy, and have only a small impact on the difficulty of understanding the claim. However, the type of benefit combined with the type of claim was found to be important for its credibility (Kleef, Trijp, \& Luning, 2005).

\subsubsection{Consumer Perceptions}

Health is an important aspect at the time of purchase, and nutrition and health claims can positively impact the time of purchase. Good nutritional information on the product label leads to a more favorable perception. Another contributor to consumers' positive image of a particular food is that consumers tend to overgeneralize the claim's health effect, believing the product to be healthy overall, even if it has only mentioned one specific aspect (Burton, Andrews, \& Netemeyer, 2000).

When consumers evaluate a food product in a context of unhealthy alternatives, i.e., high-fat foods, they have more positive attitudes and demonstrate a higher purchase intention towards the healthier product (Küster-Boluda, \& Vidal-Capilla, 2017). This suggests that direct comparisons in advertising and in-store promotions between a relatively healthy product and less healthy offerings from competitors can positively affect consumer behavior (Kozup, Creyer, \& Burton, 2003; Duarte et al., 2019).

However, consumers encounter some difficulties in evaluating nutritional information due to the presence of too much information on the package, unfamiliar terminology, difficulty interpreting the meaning of nutrients, and the relationships between calories and energy (Williams, 2005). The impact can also be negative when consumers are approached with claims containing ingredients and benefits they have not been exposed to before (Williams, 2005).

There is even a risk that healthy foods can be seen as a way to get consumers to overconsume. When consumers perceive a product as healthy, they tend to overconsume that product. For example, nutrition labels that indicate low-fat content increase consumption of those same foods because they alter consumers' perceptions of how much should be eaten (Derby \& Levy, 2005).

Beyond the difficulty in reading nutrition labels, believing a food product to be healthier does not necessarily result in consumers purchasing the product. Factors such as taste, brand, price, product attractiveness, and purchasing habits also play an important role in the purchase decision (Nocella \& Kennedy, 2012). While all of the previously mentioned factors play some role in the consumer's decision regarding whether or not to purchase a product, taste and price are the two factors with the greatest impact on the decision to purchase food products (Nocella \& Kennedy, 2012). However, according to the 
Global Health \& Wellness Survey (Nielsen, 2015), about $88 \%$ of respondents (in a sample of 30,000 individuals) said they were willing to pay more if they thought the product was healthy.

In the event that the claims are false and/or contradict the information on the nutrition information panel, the perceived credibility of the manufacturer will be reduced, and consumer evaluations will be unfavorably affected. In more extreme cases, consumers sue brands, resorting to class actions, where they accuse them of misleading use of marketing and practices that result in diseases such as obesity (Tyre, 2002).

\subsubsection{Regulation}

To mitigate some of the constraints and problems mentioned above, regulations have been produced seeking to standardize and limit claims by producers and ensure consumer safety. While food safety has been one of the key factors behind regulatory developments over the past decade, increased awareness of nutrition and health has also contributed significantly to better regulation in the food market (European Commission, 2007).

The current Regulation (EC) No. 1924/2006 was the first piece of harmonized legislation governing the use of nutrition and health claims on foods across the EU. Prior to its publication, the use of claims was controlled at the member state level and in many member states there was no control whatsoever over the use of these claims. The lack of standardization led to some constraints regarding the free movement of foodstuffs in the EU (Verhagen et al., 2012).

The regulation on health and nutrition claims applies to all commercial communications on food and drink aimed at consumers, including food supplements and dietary foods. In addition to claims made on packaging, its scope also covers advertising material, promotional campaigns, websites, catering outlets, menus, as well as brand images and trademarks (e.g., Slim-Fast!) that can be interpreted as a nutrition or health claim (Verhagen et al., 2012). The main objectives are to ensure that consumers are not misled regarding the claims made and to facilitate cross-border trade in the EU. Nutrition claims essentially convey information about what a food product contains, while health claims convey information about its effect on health. Therefore, health claims should undergo a more rigorous assessment and approval process before being authorized.
Regardless of whether a claim is considered to be a nutrition or health claim, it should comply with five general principles (European Commission, 2007), namely, it should not: be false, ambiguous, or misleading; give rise to doubt about the safety and the nutritional adequacy of other foods; encourage excessive consumption; state, suggest, or imply that a balanced and varied diet cannot provide adequate amounts of nutrients in general; refer to changes in bodily functions that could lead to increased consumer fear.

\subsection{The consumer and healthier alternatives}

\subsection{Profile of nutrition label use}

According to Viola, Bianchi, Croce, and Ceretti (2016), there is a positive correlation between reading the nutrition label on food and choosing healthier foods. Thus, it is important to understand by whom this source of information is used. The use of nutrition labels as a source of information about food is not universal, and some factors determine their greater or lesser use. According to several studies (Satia, Galanko, \& Neuhouser, 2005; Rasberry, Chaney, Housman, Misra, \& Miller, 2007; Escamilla, Himmelgreen, Haldeman, Méndez, \& Millán, 2010), women tend to use nutrition label information more than men. The information on labels also has a greater influence on (Kreuter, Brennan, Scharff, \& Lukwago, 1997 ) and induces more confidence in females (Worsley \& Lea, 2003).

Concerning age, young adults and middle-aged individuals are more likely to use nutrition labels than older individuals (Campos, Doxey, \& Hammond, 2011). However, the latter are more likely to trust the labels (Worsley, Wang, \& Hunter, 2010). Regarding younger age groups, namely adolescents, they also make little use of this type of information (Huang, Kaur, McCarter, Nazir, Choi, \& Ahluwalia, 2004). Regarding income, individuals with lower incomes are less likely to read nutrition labels (Szykman, Bloom, \& Levy, 1993). Lower-income earners are also more likely to have lower levels of nutritional knowledge (Drichoutis, Lazaridis, \& Nayga, 2005). On the other hand, higher education levels translate into greater use of nutrition labels (Huang et al., 2004).

There is also an association between nutrition label use and health practices. Individuals with healthier eating habits report greater use of nutrition labels, either due to 
personal preferences or due to dietary requirements related to a health condition (Campos et al., 2011). Consumers who spend more time selecting and purchasing food products have a higher prevalence of using the nutritional information present on labels (Lin, Lee, \& Yen, 2004), with lack of time being a reason for not paying attention to this type of information (Rasberry et al., 2007).

\subsubsection{Factors that infuence the purchase of healthier foods}

The purchase of foods that are considered to be healthier may be conditioned by personal or external factors (McGee et al., 2008). Regarding personal determinants, these may be related to the consumer's current health condition or their level of concern about their future health, whereby the greater the concern about the future and the greater the current weakness, the greater the tendency to search for healthier foods (Bos, Lans, Rijnsoever, \& Trijp, 2013). The time available for meals also proved to be important since consumers tend to consider the nutritional composition of the food they eat when they have more time available, i.e., at dinner and during vacations. On the other hand, due to lack of time, breakfast tends to be the meal where consumers pay the least attention to nutritional composition. The level of individual confidence and the level of affection for change are also personal determinants. The higher the level of these factors, the more open the consumer is likely to be to switching from traditional foods to healthier versions (McGee et al., 2008).

As for external determinants, these are related to consumers' social and cultural interactions (Stel \& van Koningsbruggen, 2015). The importance of a balanced and healthy diet for those who interact with consumers, such as family members, friends, and colleagues, will impact consumers' choices. The healthier the food choices of the social environment consumers are in, the more likely they are to eat healthily (McGee et al., 2008).

\section{Methodology}

This section outlines the steps followed in conducting the empirical study and the specific objectives and research question. This is followed by a description of the research choice, the sample selection, the form of data collection used, the location and period of collection, and the analysis technique used.
The methodology used consists of a quantitative study developed through the completion of an online questionnaire. According to Brace (2008), using a questionnaire makes it possible to obtain timely and reliable data that can be generalized to a larger population. Besides, it is usually a lower cost or even zero-cost option. The time required is less compared to qualitative studies (Santos, 1999), with the main benefit being the obtainment of more accurate results, which prevent distortions in the analysis interpretation (Brace, 2008).

In order to understand consumers' perceptions of products with nutrition and health claims, a questionnaire (Appendix 1) was developed to determine the consumer profile and target audience's perception of the so-called healthier alternatives, divided into three parts: demographics, consumer profile, and perception of healthier alternatives. These were preceded by a short introduction explaining the context and purpose of the questionnaire.

In the first section, the respondents are asked questions about their gender, age, education, employment status, and net monthly income. This first section of the questionnaire comprised only multiple-choice questions and was created with the main objective of segmenting the respondents by consumer groups, since, according to the literature review, consumer behaviors vary according to gender (Satia, Galanko, \& Neuhouser, 2005), age (Campos, Doxey, \& Hammond, 2011), income (Szykman, Bloom, \& Levy, 1993), and educational level (Huang et al., 2004).

In the second part of the questionnaire, healthy food categories, we intended to assess the importance the respondents give to their health and what they value most when purchasing food products. Regarding health, in addition to a direct question about the importance attributed to it using a Likert scale in which 1 shows that the respondent does not give any importance to their health and 5 shows that they give great importance to it, indirect questions were also asked, such as regarding their social environment, whether or not they value health (McGee et al., 2008), and whether they regularly practice sports (Campos et al., 2011). With regard to what is most valued when buying food, a table was prepared using a Likert scale, and different product attributes such as price, taste, availability, and presence of nutritional or health claims were evaluated (Nocella \& Kennedy, 2012). Additionally, the respondents were asked whether they usually read food labels (Rasberry et al., 2007) and, if not, why not (Williams, 2005). The propensity to try new foods was also questioned (McGee et al., 2008). 
The third and last part of the questionnaire, perceptions of healthier alternatives, aimed to analyze how the respondents evaluate the healthier alternatives compared to the more traditional versions and the impact that health and nutrition claims have at the moment of purchase. Initially, using multiple-choice questions, we asked which type of foods (traditional versus healthier versions) the respondents choose more, where they buy them, and if they have noticed an increase in healthier alternatives. Next, again using a Likert scale, the respondents were asked to rate different attributes such as price, taste, in-store availability, and nutritional composition of a healthier alternative versus a traditional one. Finally, through direct questions, with a yes or no answer, they were asked about the impact of a health or nutrition claim at the moment of purchase (Kozup, Creyer, \& Burton, 2003), if they confirm the veracity of the information on the nutrition label (Tyre, 2002), and if they are willing to pay more for a food that has it (Nielsen, 2015).

The platform used for the creation of the survey and subsequent means of response was Google Forms. The non-probability convenience sample method was used to choose the sample, and the questionnaire was shared on social media.

\section{Results and Discussion}

We received 477 responses within a week, with females representing $70.9 \%$ and males accounting for $30.5 \%$. The most represented individuals in the sample (56\%) were between 18 and 24 years old. As far as academic qualifications are concerned, most of the respondents had a bachelor's degree (45.9\%), with $27.2 \%$ holding a master's degree. Regarding the respondents' professional status, $50.3 \%$ of the sample were students, $30.5 \%$ worked, and $15.2 \%$ were working students. As for net monthly income earned, most of the respondents (36.2\%) said they did not earn any type of income, which is due to the fact that a substantial portion of the individuals in the sample were students. The second and third income levels most commonly earned by the respondents were in the ranges of €500-1000 (22.5\%) and €1001-1500, respectively.

\section{I Analysis of the consumer profile}

The respondents showed an interest in their diet (Graph 1), with $43 \%$ considering it to be very important and about $43.2 \%$ considering it to be important. In total, almost 9 out of 10 respondents indicated that they give importance to food. Only $12.8 \%$ of the sample individuals said they are indifferent to the importance they give to their diet and $1.05 \%$ said they give little importance to it.

According to Nocella and Kennedy (2012), the two most valued attributes when buying food are price and taste. In the sample, $90.6 \%$ of the individuals consider price to be important or very important. As for taste, an even higher percentage of individuals (96.02\%) also classify this attribute as important $(47.59 \%)$ or very important $(48.43 \%)$, corroborating the results of the study by Nocella and Kennedy (2012). As for the other attributes concerning nutritional composition, more than half of the respondents said they consider this attribute to be important $(44.86 \%)$ or very important $(20.13 \%)$. About $41.93 \%$ of the sample said they were indifferent to the brand. The value assigned to the nutritional claims was not homogeneous, with $38.99 \%$ of the individuals considering them to be important, $28.72 \%$ saying they were indifferent to them, and $15.03 \%$ attributing little

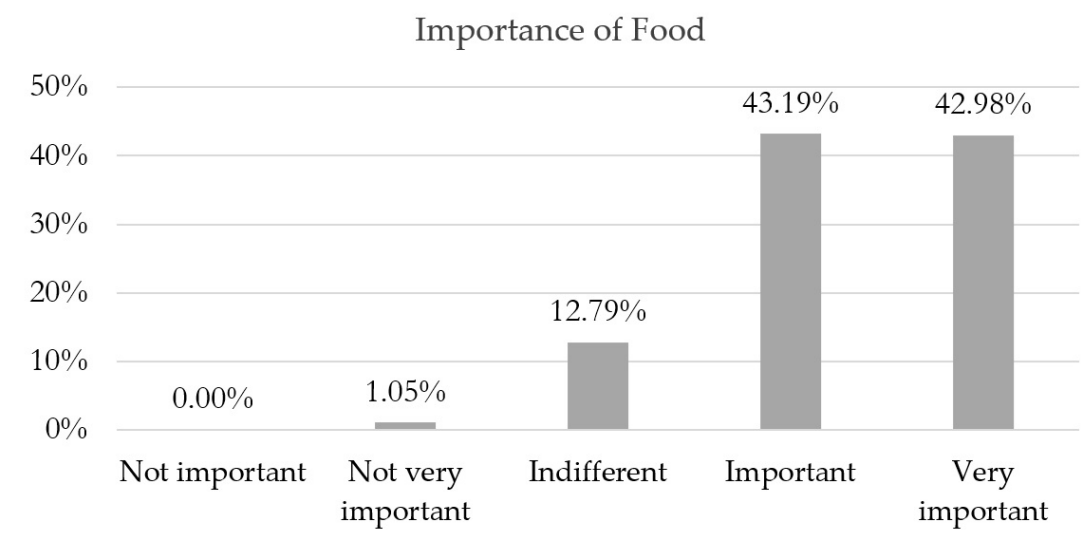

Graph 1: Importance given to food 
importance to them. Regarding the reading of nutrition labels, as suggested by Satia, Galanko, and Neuhouser (2005), most of the women (67.46\%) stated that they read nutrition labels, while only $51.08 \%$ of the men admitted to doing so. The reasons most frequently given for not doing so were not knowing the appropriate reference values for body composition, such as the percentage of energy required (38.33\%); the labels contain too much information (30\%); the terminology used is unknown to the individuals $(22.08 \%)$; or other reasons such as lack of time or interest or the fact that the font is too small (9.58\%). It is also important to note the moderate association between those who read nutrition labels and those who attach greater importance to their health.

A high percentage of respondents $(83.86 \%)$ reported having no physical condition that requires them to follow a healthier diet, so it was not possible to establish a relationship between a possible physical condition and reading nutrition labels. However, according to Bos et al. (2013), there is a positive correlation between both.

On the question of regularly practicing sports, more than half of the respondents (61.64\%) said they regularly practice sports, which together with the fact that most also read nutrition labels, confirms the conclusions reached by Campos et al. (2011), who state that there is a positive correlation between practicing sports and reading food labels. This was also found in this study, which found a moderate association between those who practice sports and those who have the habit of reading food labels.

Regarding the importance of health to the people who make up the social environment the individuals in the sample are part of, $63.94 \%$ of the respondents said that people in their social environment pay particular attention to food and nutrition issues. In addition, $67.30 \%$ of the respondents said they also have the habit of trying new foods. According to McGee et al. (2008), these two factors make individuals attribute greater importance to their diet, which is consistent with the answers obtained. Most respondents (89.10\%) also said that most of their meals are self-made and not bought ready-made.

\subsection{Perceptions about healthier alternatives}

Regarding the preference between traditional and light/zero/diet versions, the respondents still mostly opt (62.68\%) for the traditional versions. In terms of gender, although both men and women prefer the traditional versions, women are more likely to buy the so-called healthier versions (42.60\%) than men $(24.46 \%)$, which is consistent with the findings of Worsley, Wang, and Hunter (2010) and Beardsworth et al. (2002). It should also be noted that according to Cramer's V coefficient, there is a moderate association between those who read nutrition labels and those who opt for the light/diet/ zero versions (0.20). As for where the so-called healthier versions are purchased, most individuals in the sample who usually buy this type of food usually buy it in supermarkets $(82.94 \%)$ and not in specialist stores such as the Barn (4.74\%).

It has already been mentioned that several multinational companies, such as Mondelez, have been trying to increase their offer of healthier alternatives. However, consumers must become aware of these new alternatives so that they can become regular consumers. Thus, it was asked if the respondents noticed an increase in healthier options, and $84.28 \%$ answered that they did notice this increase, so it is an advantage for brands in the healthy food product market.

Regarding nutrition claims, both the female (72.78\%) and male $(59.71 \%)$ individuals stated that the presence of nutrition claims on food products increases their intentions to purchase them. This trend is also true for all age groups in the sample. Thus, in line with the findings of Burton, Andrews, and Netemeyer (2000), the individuals in the sample also suggest that health is an important aspect when purchasing, and nutrition and health claims may have a positive impact on this behavior.

Additionally, the respondents who stated that a health or nutrition claim would increase their purchase intentions were also asked if they verified the truthfulness of that claim by looking at the nutrition label, which was confirmed by $73.80 \%$ of the respondents. Thus, it is imperative for brands to make truthful claims because of their ethical and legal obligations and because, according to Tyre (2002), untruthful claims can reduce the perceived credibility of the manufacturer and adversely affect consumer evaluations.

Regarding the question on for which type of food the respondents give most importance to nutrition and health claims (Graph 2), 33.61\% mentioned dairy products, $31.94 \%$ mentioned cereals and derivatives, $22.5 \%$ mentioned oils and fats, and finally, $11.94 \%$ said they do not give importance to nutrition claims. 
In which types of foods do you place more importance on nutrition or health claims?

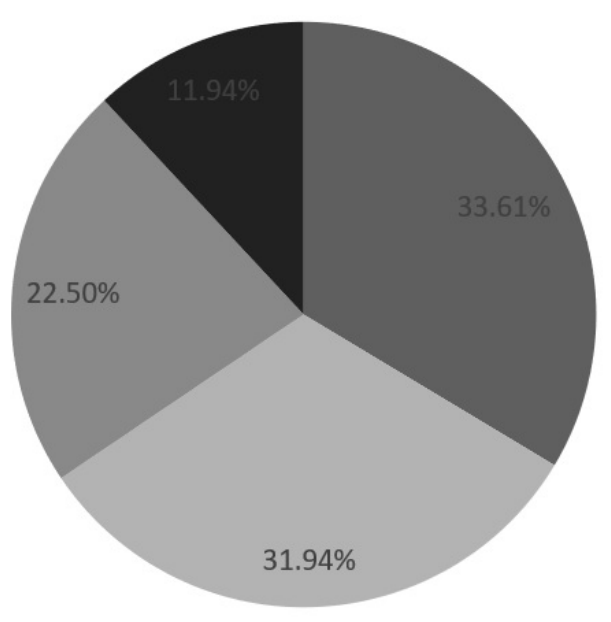

Dairy (cheese, milk, yogurt, etc.)

Fats and oils (butter, olive oil, cream, etc)

Fats and oils (butter, olive oil, cream etc)

None, I don't give importance to nutritional or health claims.

\section{Graph 2: Importance of claims per food type}

As for the willingness to pay more for these types of products, as Nielsen's Global Health \& Wellness Survey (2015) found, the consumers are willing to pay more for foods with health and nutrition claims. When comparing the income earned with this greater willingness to pay more, no trend emerged, and for all levels of income earned by the respondents, they are willing to pay more.

As for in-store availability, where 1 represents lower availability and 5 means higher availability, the respondents tended to rate it between $2(34.17 \%)$ and 3 (44.23\%), i.e., most consider that there is equal or lower availability of the healthier food alternatives in stores. For nutritional composition, with 1 being a worse nutritional composition and 5 being a better nutritional composition relative to the more traditional versions, the respondents assigned values of between 4 (40.04\%) and 5 (26.83\%), suggesting that they believe that alternatives have a better nutritional composition.

\section{Conclusions}

Food plays an important role in the lives of individuals, who for the most part consider it to be important or very important. Most of the respondents, regardless of gender, still opt for the more traditional versions, even though they have noticed an increase in the healthier alternatives available in the market. Regarding the purchase of healthier alternatives, women were more likely to purchase them than men, which confirms previous results (Escamilla et al. 2010; Worsley \& Lea, 2003). It should also be noted that those who opt for the healthier alternatives usually go to a regular supermarket and not to a specialist store such as the Barn, where the consumer possibly already knows that the prices may be higher.

Although health and nutrition claims increase the respondents' purchase intentions, it is important to note that they do not play as important a role compared to other factors such as price and taste. That is, while they may have a positive effect on purchase intentions, they are not determinative. Furthermore, when the respondents choose versions with these types of claims, they usually confirm their veracity on the label, so brands must ensure that the claims they make on labels are true and reliable. Regarding the comparison between the traditional version and healthier alternatives, the respondents find the latter more expensive, but they are also willing to pay more for them, regardless of their income (Van Ittersum $\&$ Wansink, 2010). Most of the respondents also do not report noticing major differences in taste, contrary to what was anticipated. Finally, they report that the healthier alternatives' nutritional composition is better, which, together with a greater concern for food, should lead the respondents to choose the healthier versions. If not, they reinforce the previously presented idea that, 
although the nutritional composition is important, it is not the attribute most taken into account at the time of purchase. The availability of the products on the shelves, however, seems to be important. These results are in line with the findings of Hawkes (2008), who concluded that supermarkets play a very important role in the adoption of healthier purchasing behaviors. In the study, it was considered essential to offer an assortment of such products to an increasing number of individuals who choose this channel for their food purchases, which gives supermarkets a relevant social role (Dibb et al., 2005) and opens up space for public policies aimed at the adoption of healthier eating behaviors to include actions at the distribution channel level and not only at the communication channel level. Thus, we are led to think that if supermarkets can induce the consumption of food products by presenting themselves as showcases of a huge variety of products, accessible to a large part of the population, just as they can induce the consumption of less healthy products, they can also - through the assortment made available - stimulate the purchase of products that are richer from a nutritional point of view.

According to the results obtained, it can also be argued that investment in promotional campaigns in supermarkets, targeting mainly female individuals, emphasizing health and nutrition claims, is more likely to positively impact the sales of these foods. Additionally, a greater emphasis on food labels of nutritional benefits for athletes would also be valued by consumers, as those who play sports regularly are more likely to read labels.

Despite the efforts made when carrying out this research, it has some limitations, namely in terms of the sample studied, which is mainly composed of young adults and cannot represent the Portuguese population. In line with Hawkes (2008), it is important to assess how different generations react to claims. As consumption decisions for households are usually made by women (Inglis, Ball, \& Crawford, 2009) of a generation above the one studied, it would be important to know how older people react to these claims.

It would also be interesting to know why more conventional versions continue to be preferred over healthier ones even by individuals who reveal that they attach great importance to their health and are willing to pay more for those alternatives they recognize as having a better nutritional composition. This point raises questions of whether this choice of the more traditional versions is due to some overlooked attribute. Is it simply a matter of consumer habits and resistance to change, or perhaps the understanding that the healthier options contain ingredients that are not better for health? In the latter case, it may be necessary for brands to invest more in technical and functional claims and less in emotional ones.

Future investigations could address different factors that influence the buying process, as well as choosing a more representative sample from the population.

\section{Acknowledgments}

The authors would like to thank NECE Research Unit in Business Sciences, funded by the Multiannual Funding Programme of R\&D Centres of FCT - Fundação para a Ciência e a Tecnologia, under project n. UIDB/04630/2020, and CEGE - Research Centre in Management and Economics, funded by the Multiannual Funding Programme of R\&D Centres of FCT - Fundação para a Ciência e a Tecnologia, under project n. UIDB/00731/2020.

\section{References}

Aschemann-witzel, J., Maroscheck, N., \& Hamm, U. (2013). Are organic consumers preferring or avoiding foods with nutrition and health claims? Food Quality and Preference, 30(1), 68-76.

Beardsworth, A., Bryman, A., Keil, T., Goode, J., Haslam, C., \& Lancashire, E. (2002). Women, men and food. The significance of gender for nutritional attitudes and choices. British Food Journal, 104(7), 470-491.

Bos, C., Lans, I. A. Van Der, Rijnsoever, F. J. Van, \& Trijp, H. C. M. Van. (2013). Understanding consumer acceptance of intervention strategies for healthy food choices: a qualitative study. BMC Public Health, 2013 Nov 13;13:1073, 1-14.

Brace, I. (2008). Questionnaire design: how to plan, structure and write survey material for effective market research. Second Edition. Kogan Page. London.

Burton, S., Andrews, J. C., \& Netemeyer, R. G. (2000). Nutrition Ad Claims and Disclosures: Interaction and Mediation Effects for Consumer Evaluations of the Brand and the Ad. Marketing Letters, 11(3), 235-247. 
Campos, S., Doxey, J., \& Hammond, D. (2011). Nutrition labels on pre-packaged foods: a systematic review. Public Health Nutrition, 14(8), 1496-1506.

Derby, B., \& Levy, A. (2005). Effects of Strength of Science Disclaimers on the Communication Impacts of Health Claims. Retrieved from https://www.researchgate. net/publication/242685462_Effects_of_Strength_of_ Science_Disclaimers_on_the_Communication_Impacts_ of_Health_Claims, on 12/28/2020.

Dibb, S. (2005) Healthy Competition: How Supermarkets Can Affect your Chances of Healthy Diet. London: National Consumer Council.

Drichoutis, A. C., Lazaridis, P., \& Nayga, R. M. (2005). Nutrition knowledge and consumer use of nutritional food labels. European Review of Agricultural Economics, 32(1), 93-118.

Duarte, P., Silva, S., Pisco, A. \& Campos, J. M. (2019), Orthorexia Nervosa: Can Healthy Eating Food Trends Impact Food Companies Marketing Strategies? Journal of Food Products Marketing, 25(7), 754-770.

Escamilla, R. P., Himmelgreen, D., Haldeman, L., Méndez, I., \& Millán, S. (2010). Ecology of Food and Nutrition knowledge, attitudes, and behaviors among Latinos in the USA: Influence of language. Ecology of Food and Nutrition 40(4), 321-345

European Commission. (2007). Regulation 1924/2006, European Commission request to the European Food Safety Authority for scientific advice on the Community list of permitted health claims pursuant article 13 of Regulation 1924/2006 on nutrition and health claims made on foods, 13(3), 1-5.

European Court of Auditors (2012). Auditoria Do Sistema De Control Aplicável À Produção, Transformação, Distribuição e Importação de Produtos Biológicos, Special report 9, Publications Office of the European Union, Luxembourg. (doi:10.2865/50111)

German, B., Schiffrin, E. J., Reniero, R., Mollet, B., \& Pfeifer, A. (1999). The development of functional foods: lessons from the gut. Trends in Biotechnology, 17(12), 492-499.
Gravel, K., Doucet, É., Herman, C. P., Pomerleau, S., \& Bourlaud, A. (2012). "Healthy," "diet" or "hedonic"? How nutrition claims affect food-related perceptions and intake? Appetite, 59(3), 877-884.

Hanson, N., \& Yun, W. (2018). Should "big food" companies introduce healthier options? The effect of new product announcements on shareholder value. Marketing Letters, 29(1), 1-12.

Helga, W., \& Yussefi, M. (2007). The World Of Organic Agriculture Statistics And Emerging Trends 2007, International Federation of Organic Agriculture Movements IFOAM, Bonn, Germany \& Research Institute of Organic Agriculture FiBL, Frick, Switzerland. Available at: https:// orgprints.org/10506/1/willer-yussefi-2007-p1-44.pdf, consulted in 18/9/2020.

Hawkes, C. (2008). Dietary implications of supermarket development: a global perspective. Development Policy Review, 26(6), 657-692.

Huang, T., Kaur, H., McCarter, K., Nazir, N., Choi, W., \& Ahluwalia J. (2004). Reading Nutrition Labels and Fat Consumption in Adolescents. Journal of Adolescent Health, 35(5), 399-401.

Hung, Y., Grunert, K. G., Hoefkens, C., Hieke, S., \& Verbeke, W. (2017). Motivation outweighs ability in explaining European consumers' use of health claims. Food Quality and Preference, 58(June), 34-44.

Inglis, V., Ball, K., \& Crawford, D. (2009). Does modifying the household food budget predict changes in the healthfulness of purchasing choices among low-and high-income women? Appetite, 52(2), 273-279.

Kantar World Panel (2018). Saudável: Moda passageira ou estilo de vida assumido? - Retrieved from https:// www.kantarworldpanel.com/pt/news/Saudvel-Modapassageira-ou-estilo-de-vida-assumido in 28/12/2020.

Kaur, S., \& Das, M. (2011). Functional Foods: An Overview. Food Science and Biotechnology, 20(4), 861-875.

Kleef, E. Van, Trijp, H. C. M. Van, \& Luning, P. (2005). Functional foods: health claim-food product compatibility and the impact of health claim framing on consumer evaluation. Appetite, 44(3), 299-308. 
Kozup, J. C., Creyer, E. H., \& Burton, S. (2003). Making Healthful Food Choices: The Influence of Health Claims and Nutrition Information on Consumers' Evaluations of Packaged Food. Journal of Marketing, 67(2), 19-34.

Kreuter M., Brennan, L., Scharff, D., \& Lukwago, S. (1997). Do nutrition label readers eat healthier diets? Behavioral correlates of adults' use of food labels. American Journal of Preventive Medicine, 13(4), 277-283.

Küster-Boluda, I., \& Vidal-Capilla, I. (2017). Consumer attitudes in the election of functional foods. Spanish Journal of Marketing - ESIC, 21(S1-July), 65-79.

Lee, H., \& Yun, Z. (2016). Consumers' perceptions of organic food attributes and cognitive and affective attitudes as determinants of their purchase intentions toward organic food. Food Quality and Preference, 39(1), 259-267.

Lin, C., Lee, J., \& Yen, S. (2004). Do dietary intakes affect search for nutrient information on food labels? Social Science \& Medicine, 59(9), 1955-1967.

Loebnitz, N., \& Grunert, K. G. (2018). Impact of self-health awareness and perceived product benefits on purchase intentions for hedonic and utilitarian foods with nutrition claims. Food Quality and Preference, 64, 221-231.

McGee, B. B., Richardson, V., Johnson, G. S., Thornton, A., Johnson, C., Yadrick, K., McCabe-Sellers, B. (2008). Perceptions of Factors Influencing Healthful Food Consumption Behavior in the Lower Mississippi Delta: Focus Group Findings. Journal of Nutrition Education and Behavior, 40(2), 102-109.

Mcneal, J. U. (2007). On Becoming A Consumer, The Development of Consumer Behavior Patterns In Childhood, Elsevier Inc., USA, p. 19.

Menrad, K. (2003). Market and marketing of functional food in Europe. Journal of Food Engineering, 56(2-3), $181-188$.

Meziane, Z. (2007). Future innovations in food and drinks to 2012: NPD, trend convergence and emerging growth opportunities. Business insights, Available in: http://rnavi.ndl.go.jp/mokuji_html/000009178490.html Consulted in 28/12/2020.
Nielsen (2015). Global Health and Wellness Report - We are what we eat healthy eating trends around the world. The Nielsen Company. New York.

Nocella, G., \& Kennedy, O. (2012). Food health claims What consumers understand. Food Policy, 37(5), 571-580.

Nunes, C., Pereira, J. (2016). Visão | Os negócios da comida saudável. Revista Exame. Available in: http:// visao.sapo.pt/exame/2016-02-03-Os-negocios-da-comidasaudavel, in 20/4/2020.

Ramalho, S. (2017). Como o Continente quer ser mais saudável. Revista Distribuição Hoje, 28 de novembro. Available in: https://www.distribuicaohoje.com/retalho/ continente-quer-saudavel/ in 2/2/2020.

Rasberry, C. N., Chaney, B. H., Housman, J. M., Misra, R., \& Miller, P. J. (2007). Determinants of Nutrition Label Use Among College Students. American Journal of Health Education, 38(2), 76-82.

Saba, A., Vassallo, M., Shepherd, R., Lampila, P., Arvola, A., Dean, M., Winkelmanne, M., Claupeine, E., Lähteenmäki, L. (2010). Country-wise differences in perception of health-related messages in cereal-based food products. Food Quality and Preference, 21(4), 385-393.

Santos, S. (1999). Métodos qualitativos e quantitativos na pesquisa biomédica. Jornal de Pediatria, 75(6), 401-406.

Satia, J., Galanko, J., \& Neuhouser, M. (2005). Food Nutrition Label Use Is Associated with Demographic, Behavioral, and Psychosocial Factors and Dietary Intake among African Americans in North Carolina. Journal of the American Dietetic Association, 105(3), 392-402

Shields, M., \& Tremblay, M. S. (2008). Sedentary behaviour and obesity. Health Reports, 19(2), 19.

Stagl, S. (2002). Local Organic Food Markets: Potentials and Limitations for Contributing to Sustainable Development. Empirica, 29(2), 145-162.

Stel, M., \& van Koningsbruggen, G. M. (2015). Healthy food consumption in young women. The influence of others' eating behavior and body weight appearance. Appetite, 90(June), 240-247. 
Szykman, L., Bloom, P., \& Levy, A. (1993). A Proposed Model of the Use of Package Claims and Nutrition Labels. Journal of Public Policy \& Marketing, 6(2), 228-241.

Trijp, H., \& Lans, I. (2007). Consumer perceptions of nutrition and health claims. Appetite, 48(3), 305-324.

Tyre, P. (2002). Fighting 'Big Fat': An Army Is Mobilizing in a War against Junk Food. the Combatants: Doctors, Lawyers, Preachers and Moms. Newsweek, August 5, 2002. Available from https://nepc.colorado.edu/sites/ default/files/CERU-0208-08-OWI.pdf. Consulted on $12 / 28 / 2020$.

Van Ittersum, K.P.J. \& Wansink B (2010). Trying Harder and Doing Worse: How Grocery Shoppers Track In-Store Spending, Journal of Marketing, 74(2):1-32.

Verhagen, H., Vos, E., Francl, S., Heinonen, M., \& Loveren, H. Van. (2012). Status of nutrition and health claims in Europe q Nutrition claims Health claims Function claims. Archives of Biochemistry and Biophysics, 501(1), 6-15.
Viola, G., Bianchi, F., Croce, E., \& Ceretti, E. (2016). Are food labels effective as a means of health prevention? Journal of Public Health Research, 5(3), 139-142.

Williams, P. (2005). Consumer Understanding and Use of Health Claims for Foods. Nutrition Review, 63(7), 256-264.

World Health Organization (2007). A safer future, Global Public Health Security in the 21ST Century. Geneva, Switzerland.

World Health Organization. (2018). World Health Statistics 2018. Geneva, Switzerland.

Worsley, A., \& Lea, E. (2003). Consumers' personal values and sources of nutrition information. Ecology of Food and Nutrition, 42(2), 129-151.

Worsley, A., Wang, W.C., Hunter, W., 2010. Baby boomers' food shopping habits. Relationships with demographics and personal values. Appetite, 55(3), 466-472. 


\section{Appendix 1}

Questionnaire

Percepção dos consumidores em relação a produtos com alegações nutricionais e de saúde

\section{Dados demográficos}

Sexo
o Feminino
o Masculino

\section{Idade}
o Até 18 anos
o $18-24$
o $25-34$
o $35-44$
o $45-54$
o $55-64$
$0+65$ anos

Formaçáo acadêmica
o Ensino Fundamental
o Ensino Médio
o Graduação
o Mestrado
o Doutorado
o Outro:

\section{Situaçáo profissional}
o Empregado
o Estudante
o Trabalhador-Estudante
o Desempregado
o Aposentado
o Outra:

\section{Qual é sua renda mensal?}
o Menos de $500 €$
o $500 €-1000 €$
o $1001 €-1500 €$
o $1501 €-2000 €$
o $2001 €-2500 €$
o $2501 €-3000 €$
o Mais de $3000 €$
o Não sabe / Não responde
o Sem renda

\section{Perfil do consumidor}

Avalie de 1 (nada importante) a $\mathbf{5}$ (muito importante) a importância que você dá à sua alimentaçáo: ( 1 = Nada importante; 2 = Pouco importante; 3 = Indiferente; 4 = Importante; 5 = Muito importante)

\begin{tabular}{|l|l|l|l|l|}
\hline 1 & 2 & 3 & 4 & 5 \\
\hline & & & & \\
\hline
\end{tabular}


Avalie de 1 (nada importante) a 5 (muito importante) a importância que você dá a cada aspecto no momento de compra de produtos alimentícios:

\begin{tabular}{|l|l|l|l|l|l|}
\hline & $\mathbf{1}$ & $\mathbf{2}$ & $\mathbf{3}$ & $\mathbf{4}$ & $\mathbf{5}$ \\
\hline Preço & & & & & \\
\hline Sabor & & & & & \\
\hline Alegaçóes de saúde e nutricionais & & & & & \\
\hline Composição nutricional & & & & & \\
\hline Marca & & & & & \\
\hline
\end{tabular}

Você tem o hábito ler os rótulos de produtos alimentícios?

o $\operatorname{Sim}$

o Não

Se você respondeu náo à questáo anterior, por quê? (É possível assinalar mais de uma resposta)

o Muitas informaçôes

o Terminologia desconhecida

o Não sabe quais os valores de referência para sua composição corporal

o Outra:

Você tem alguma condiçáo física que o obrigue a fazer uma alimentação mais saudável? (Por exemplo, diabetes, colesterol elevado, alergias etc.)

o $\operatorname{Sim}$

o Não

Você se considera uma pessoa fisicamente ativa? (Faz atividade física regularmente)

o $\operatorname{Sim}$

o Não

Você considera que seu meio social (família, amigos, colegas) dá particular atençáo às questóes alimentares e nutricionais?

o Sim

o Não

Você tem o hábito experimentar alimentos novos?

o Sim

o Não

A maioria das refeiçóes que você faz sáo feitas por você ou compradas prontas?

o Feitas por mim

o Compradas (cafés, restaurantes, refeiçóes rápidas ou snacks em supermercados)

Percepção sobre as alternativas mais saudáveis

Você costuma optar pelas versóes tradicionais ou light/diet/zero?

o Versôes tradicionais

o Versōes light/diet/zero

Se você opta pelas versóes light/diet/zero, onde as compra?

o Supermercados

o Lojas especializadas (Celeiro, Go Natural etc.)

Você notou um aumento das versóes light/diet/zero no mercado?

o Sim

o Não

Uma alegaçáo de saúde ou nutricional faria aumentar suas intençóes de compra? (Exemplo de uma alegação: mais fibra adicionada/menos gordura)

o Sim

o Não 
Se você respondeu sim à questáo anterior, confirma a veracidade da alegaçáo na tabela nutricional fornecida no rótulo dos produtos alimentícios?

o Sim

o Não

Em que tipos de alimentos você dá mais importância às alegaçóes nutricionais ou de saúde?

o Leite e derivados (queijo, leite, iogurte etc.)

o Cereais e derivados (arroz, massa, biscoitos etc.)

o Gorduras e óleos (manteiga, azeite, natas etc.)

o Nenhum, não dou importância às alegaçôes nutricionais ou de saúde.

Você está disposto a pagar mais por essas alternativas consideradas mais saudáveis?

o Sim

o Não

Compare as características das alternativas mais saudáveis com as versóes mais tradicionais:

\begin{tabular}{|l|l|l|l|l|l|l|}
\hline & $\mathbf{1}$ & $\mathbf{2}$ & $\mathbf{3}$ & $\mathbf{4}$ & $\mathbf{5}$ & \\
\hline Mais barato & & & & & & Mais caro \\
\hline Menos saboroso & & & & & & Mais saboroso \\
\hline Menor disponibilidade em loja & & & & & & Maior disponibilidade em loja \\
\hline Pior composição nutricional & & & & & & Melhor composição nutricional \\
\hline
\end{tabular}

\section{Financial support:}

The authors would like to thank NECE - Research Unit in Business Sciences, funded by the Multiannual Funding Programme of R\&D Centres of FCT - Fundação para a Ciência e a Tecnologia, under project n. UIDB/04630/2020, and CEGE - Research Centre in Management and Economics, funded by the Multiannual Funding Programme of R\&D Centres of FCT - Fundaçấo para a Ciência e a Tecnologia, under project n. UIDB/00731/2020.

\section{Conflicts of interest:}

The authors have no conflict of interest to declare.

\section{Copyrights:}

RBGN owns the copyrights of this published content.

\section{Plagiarism analysis:}

RBGN performs plagiarism analysis on all its articles at the time of submission and after approval of the manuscript using the iThenticate tool.

\section{Authors:}

1. Paulo Duarte, PhD., Universidade da Beira Interior, Covilhã (Portugal). pduarte@ubi.pt

2. Mariana Teixeira, MSc, Universidade Católica Portuguesa, Porto (Portugal). marianapteixeira@gmail.com

3. Susana Costa e Silva, PhD., Universidade Católica Portuguesa, Porto (Portugal). ssilva@porto.ucp.pt

\section{Authors' Contributions:}

Paulo Duarte: Definition of research problem; Development of hypotheses or research questions (empirical studies); Definition of methodological procedures; Statistical analysis; Analysis and interpretation of data; Critical revision of the manuscript; Manuscript writing.

Mariana Teixeira: Definition of research problem; Development of hypotheses or research questions (empirical studies); 
Definition of methodological procedures; Data Collection; Literature review; Statistical analysis; Analysis and interpretation of data; Manuscript writing.

Susana Costa e Silva: Definition of research problem; Analysis and interpretation of data; Critical revision of the manuscript; Manuscript writing. 